\title{
COMPARING OF MESOPHILIC AND THERMOPHILIC ANAEROBIC FERMENTED SEWAGE SLUDGE BASED ON CHEMICAL AND BIOCHEMICAL TESTS
}

\author{
KARDOS, L. ${ }^{1}{ }^{*}$, JUHÁSZ, Á. ${ }^{1}$, PALKÓ, GY. ${ }^{2}$, OLÁH, J. ${ }^{2}$, BARKÁCS, K. ${ }^{3}$, ZÁRAY, GY. ${ }^{3}$ \\ ${ }^{I}$ Department of Soil Science and Water Management, Corvinus University of Budapest \\ H-1118 Budapest, Villányi út 29-43., Hungary \\ (phone: +36-1-482-6466; fax: +36-1-428-6336) \\ ${ }^{2}$ Budapest Sewage Works Ltd. \\ H-1087 Budapest, Asztalos Sándor utca 4., Hungary \\ (phone: +36-1-455-4100; fax: +36-1-459-1600) \\ ${ }^{3}$ Cooperative Research Center for Environmental Sciences, Eötvös Loránd University \\ H-1117 Budapest, Pázmány Péter sétány 1/a, Hungary \\ (phone: +36-1-372-2607; fax: +36-1-372-2608) \\ *Corresponding author \\ e-mail: levente.kardos2@uni-corvinus.hu \\ (Received 31 ${ }^{\text {st }}$ August 2011; accepted $7^{\text {th }}$ October 2011)
}

\begin{abstract}
In the course of anaerobic sludge treatment (digestion) biogas can be acquired from the sludge, its use for energetic purposes has a determinative significance in a wastewater treatment plant. The biogas, produced in the course of decomposition, covers - among others - a considerable portion of the heat- and electric energy consumption in a wastewater treatment plant, thus an increase of the biogas volume is an outstanding task. It is possible to increase the biogas volume if the anaerobic digestion processes are thoroughly well known. The anaerobic digestion process is determined by temperature, substrate composition, loading, and also by toxic substances that might be present. In our experimental work the thermophilic and mesophilic full scale anaerobic bioreactors of a communal sewage treatment plant were tested by applying usual control parameters and enzyme activity tests.
\end{abstract}

Keywords: anaerobic fermentation, thermophilic, mesophilic, biogas

\section{Introduction}

Biogas with methane may be produced during the anaerobic fermentation process of the sewage sludge. Usage of the biogas can be really importanat in the electric power supply of the wastewater treatment plant. Biogas derived from the fermentation can cover the greatest part of the power and electric needs of the plant thatswhy one of the most important tasks is to increase its volume. Biogas is a renewable and sustainable energy source. Biogas can be produced from solid and liquid wastes (for example: sewage sludge, agricultural or food industrial wastes). Biogas will act the part of renewable energy sources in the world. India has the second largest biogas and improved stove programme in the world (Raghuvanshi et al., 2008). For growing the biogas volume we have to understand more detailed the anaerobic fermentation process, which is determined by temperature, substrate composition, load, and toxic materials which might be presented (Schroeder, 1977; Malina and Pohland, 1992). In our study we compared anaerobic fermentation made on thermophilic and mesophilic temperatures on full scale anaerobic bioreactor by applying usual control parameters 
(pH, volatile acid content, alkalinity, gas composition) and by enzyme activity (dehydrogenase, protease, lipase) tests.

Investigation of the methane gas production depended on temperature has been existing for a long time. Methane gas production starts above $0^{\circ} \mathrm{C}$ (phsichrofil range: 0 $25^{\circ} \mathrm{C}$ ) then with the increasing temperature gas volume is growing. Temperature's role in the anaerobic decomposition has been investigated by many authors (Fair and Moore, 1934; Goulecke, 1958; Hills and Schroeder, 1969) who suggested the mesophilic range $\left(35-40^{\circ} \mathrm{C}\right)$ for optimal methane producing temperature, and reported drastic decrease in gas production above $42^{\circ} \mathrm{C}$ (Fair and Moore, 1934; Hills and Schroeder, 1969). Nowadays it is known that there are two optimal temperature intervals (Malina and Pohland, 1992). The optimal temperature of the mesophilic range is about $55^{\circ} \mathrm{C}$. Based on economical considerations the mesophilic (at about $35^{\circ} \mathrm{C}$ ) and the thermophilic (at about $55^{\circ} \mathrm{C}$ ) decomposition have spreaded in everyday practice. Mesophilic range is: $25-45^{\circ} \mathrm{C}$ while thermophilic is: $45-60^{\circ} \mathrm{C}$. Malina and Pohland (1992) reported drastic gas production decreasing above $60^{\circ} \mathrm{C}$ and ceasing above $70^{\circ} \mathrm{C}$. Kardos et al. (2009) had the same results in their investigation made in pilot plant scale. The mesophilic fermentation is still in the first place in the sludge treatment however the thermophilic fermentation proccesses higher decomposition efficiency, thatswhy bigger gas volume, and shorter hydraulic retention time. Comparison of the mesophilic and thermophilic fermentations can be seen in the Table 1. Table 2 contains their advantages and the Table 3 includes their disadvantages. The tables (Table 1, Table 2, Table 3) were set up from results of many experiments made in pilot and full plant scales by many authors (Ahring, 1994; Aitken et al., 1992; Garber, 1982; Iranpour et al., 2002; Moen et al., 2003; Nielsen, 1999; Nielsen et al., 2001; Rimkus et al., 1982; Zábránská et al., 2000a, 2000b, 2002).

Table 1. Comparison of mesophilic and thermophilic fermentation based on operating and controlling parameters

\begin{tabular}{c|c|c}
\hline Parameter & Mesophilic system & Thermophilic system \\
\hline Optimal temperature $\left({ }^{\circ} \mathrm{C}\right)$ & $35-40$ & $55-60$ \\
pH & $7.2-8.0$ & $7.2-8.5$ \\
Temperature's fluctuation tolerated by & $3-5$ & $1-2$ \\
the system $\left({ }^{\circ} \mathrm{C}\right)$ & $15-25$ & $3-10$ \\
Hydraulic retention time (d) & $65-85$ & $85-95$ \\
Max. COD reduction (\%) & $60-80$ & $80-90$ \\
Max. BOD reduction $(\%)$ & $45-55$ & $55-70$ \\
Max. organic material reduction $(\%)$ & $920-980$ & $950-1000$ \\
Biogas production $\left(\mathrm{Nm}^{3} / 1000 \mathrm{~kg}\right.$ dry & $60-70$ & $70-85$ \\
organic material) & $1500-2500$ & $3000-4000$ \\
Methane gas content of the biogas $(\%)$ & $4000-6000$ & $3000-5000$ \\
Volatile acid $\left(\mathrm{mg} \mathrm{CH}_{3} \mathrm{COOH}^{3} \mathrm{dm}^{3}\right)$ & & \\
Alkalinity $\left(\mathrm{mg} \mathrm{CaCO}_{3} / \mathrm{dm}^{3}\right)$ &
\end{tabular}

Explanation: COD: chemical oxygen demand; $\mathrm{BOD}_{5}$ : five days biochemical oxygen demand

To see the Table 1 it is remarkable that the results of enzyme activity measurements are missing. Application of the results of the enzyme activity investigations can be usefull in the plant control process, because hidrolysis processes - as the first steps of 
the anaerobic digestion and beeing also fermenetation's speed determining - can be described by them (Thiel and Hattingh, 1967).

Table 2. Advantages of the mesophilic and thermphilic systems

\begin{tabular}{c|c}
\hline $\begin{array}{c}\text { Mesophilic system } \\
\text { (related to the unstabilised sludge) }\end{array}$ & $\begin{array}{c}\text { Thermophilic system } \\
\text { (related to the mesophilic system) }\end{array}$ \\
\hline during the biogas production organic material is \\
stabilising; fermented sludge can be applied as \\
dung & $\begin{array}{c}\text { increased gas output due to the faster reaction; } \\
\text { higher methane gas content and reduces hydrogen- } \\
\text { sludge's quantity reducing }\end{array}$ \\
sulfid content in the biogas \\
staying-duration shorter \\
sludge's fertilisation ability reducing & smaller reactor volume demand \\
sludge's water downtake capacity getting better & more patogen's distruction \\
& sludge's dehydratation getting better \\
& reduced foam formation in the reactor \\
\hline
\end{tabular}

Table 3. Disadvantages of the mesophilic and thermophilic systems

\begin{tabular}{c|c}
\hline $\begin{array}{c}\text { Mesophilic system } \\
\text { (related to the unstabilised sludge) }\end{array}$ & $\begin{array}{c}\text { Thermophilic system } \\
\text { (related to the mesophilic system) }\end{array}$ \\
\hline $\begin{array}{c}\text { due to the longer staying duration - larger reactor } \\
\text { volume demand, higher investment's costs } \\
\text { sludgewater's quality getting worse }\end{array}$ & higher heater energy demand \\
fermentation blocking influence of heavy metals & $\begin{array}{c}\text { sludgewater's quality getting worse } \\
\text { sensitivity to the sudden temperature fluctuation, } \\
\text { more precise temperature regulation demand } \\
\text { sensitivity to the toxic heavy metals }\end{array}$ \\
\hline
\end{tabular}

In spite of some disadvantages of the thermophilic system, it is more favourable than the mesophilic one, because of its larger gas output capacity and higher methane gas content. Neverthless the mesophilic systems have been usual in the fermentation process. An anaerobic digestion process consists of several sub-processes. According to Lawrance and McCarty (1969) and Malina and Pohland (1992) in an anaerobic digestion process also three steps are existing: hydrolysis, acid production, methane production. However essentially only two phases the acidic and methane phases must be dealt with, as the process of hydrolysis is also carried out by the acid producing bacteria. In the course of the hydrolysis - due to the effect of the extracellular enzymes of acid producing bacteria - the large moleculas in the solid sludge are decomposed into symple carbohydrates, amino acids and fatty acids. Thus this step and its rate has a deterministic role in the process of the methane production. The substrate's degradation can be described by the hydrolytic enzym activity, as the decomposition speed depends on that (Thiel et al., 1968).

For describing anaerobic processes the use of several methods has been tested. Chung and Neethling (1988) suggested to determine the concentration of ATP (adenosine-5-thriphospate) since its concentration and the rate of gas production are in close relationship with each other and these two parameters property describe the activity of an anaerobic system. In certain cases the measurements of hydrogen can adequately describe the equilibrium of the methane producing phase (Mosey and Fernandez, 1988). However following hydrogen usage is only one way to control methane production, thus is not really typical of the total methane production process. For controlling the operation of anaerobic fermenters, the use of hydrolytic enzyme activity tests were already proposed by Thiel and Hattingh in their article published in 1967. 
Since than more authors (Goel et al., 1998; Li and Chróst, 2006) tried to follow the enzyme activity processes by measurements but for daily control this applications have not become part of the control parameters, only the usual control parameters $(\mathrm{pH}$, volatile acid content, alkalinity, gas composition) are used in the practise. From the plant operation point of view it is very important to control and to intervene the anaerobic fermentation process in every cases, if it is needed.

In the following we describe our investigations made in full scale plant with the usually applied parameters $(\mathrm{pH}$, volatile acid content, alkalinity, gas volume, gas composition) and biochemical parameters (dehydrogenase, protease, lipase) based on our former pilot plant investigations (Kardos et al., 2009).

\section{Materials and methods}

The investigations was carried out at a communal sewage treatments plant in Budapest (Budapest Sewage Works Ltd., South-Pest Wastewater Treatment Plant). In our work we investigated the usually applied control parameters and the relation of enzyme activity and gas output in mesophilic and thermophilic towers.

At the sewage treatment plant there are three mesophilic anaerobic fermenters $\left(2600 \mathrm{~m}^{3}\right.$ each) and one thermophilic anaerobic reactor of $2000 \mathrm{~m}^{3}$. From both of them, one was investigated. The most important operating parameters of 50 days investigations can be seen in the Table 4 .

Table 4. The average daily values of the operating parameters over the experimental period $(n=50)$

\begin{tabular}{|c|c|c|}
\hline Parameters & Mesophilic system & Thermophilic sytem \\
\hline Temperature $\left({ }^{\circ} \mathrm{C}\right)$ & $35.6 \pm 0.6$ & $54.6 \pm 0.5$ \\
\hline $\begin{array}{l}\text { Specific organic material load } \\
\qquad\left(\mathrm{kg} / \mathrm{m}^{3} * \mathrm{~d}\right)\end{array}$ & $3.24 \pm 0.74$ & $2.10 \pm 0.76$ \\
\hline Hydraulic retention time (d) & $16.45 \pm 1.25$ & $5.65 \pm 0.45$ \\
\hline
\end{tabular}

In our work the control parameters were investigated, such as total volatile fatty acid, alkalinity, gas composition, $\mathrm{pH}$, dry and organic material content of the sludge. These parameters were measured on the basis of the requirements given in the Standard Methods. Gas composition of the biogas was determined according to the Hungarian Standard (MSZ5313-57) based on the absorbancy of the gas components and also on burning methane. The produced gas quantity was measured by gas volume registrating system.

For the enzyme activity measurements has not existed international standard, so the determination of the measurements method is published in this work. Before their application, receipt's adaptation investigations on anaerobic sewage sludge samples were made based on former scientific literature's data.

\section{Dehydrogenase enzyme activity}

The dehydrogenase activity was measured on the basis of García et al. (1993), Skujins (1976), Griebe et al. (1997) and the Hungarian Standard No. (MSZ-08-1721/386). Satureted $\mathrm{NaHCO}_{3}$ as a buffer, and 2,3,5-triphenyltetrazolium chloride (TTC) as a substrate were added to the digested sewage sludge sample. Then for one hour the samples were stopped by ethanol. After filtering, the solution's absorbancy-applying 
ethanol as blank was measured at $485 \mathrm{~nm}$. The obtained absorbancies were evaluated using calibrations. The calibration series contained triphenyl-phormazane (TP) in known concantration as - due to the result of the process catalyzed by the enzyme TTC transforms its quantity could be measured by spectrophotometry. The activity is expressed in triphenyl-phormazane mass produced by a unit weight of dry organic sludge per hour.

\section{Protease enzyme activity}

The protease activity measurement was carried out on the basis of Thiel and Hattingh's method (1967). In these test series casein solution was used as a substrate. Each sample contained 1/3 part sludge sample, 1/3 part substrate and 1/3 part distilled water. After incubation at room temperature for 1 hour the reaction was stopped by trichloroacetic acid. After alkalization, which followed filtering-due to the separated iron precipitate- it was refiltered and adding diluted Folin-reagent the appearing blue clolour was measured at $660 \mathrm{~nm}$. As a blank, anaerobic sludge treated in the above rations without incubation was used, immediately after its treatment with trichloroacetic acid. The measured data were evaluated by L-tyrosine calibration. The activity is expressed in tyrosine quantity produced during one hour by a unit mass of dry organic sludge.

\section{Lipase enzyme activity}

Lipase enzyme activity was measured according to Vorderwülbecke et al. (1992) and Li and Chróst (2006). For carrying out these tests the emulsion of two reagent solutions (containing 4-nitrophenyl palmitate-NPP-as substrate) had to be prepared then its predetermined portion was added into the supernatant of the centrifuged sludge. The incubation time was one hour at $45^{\circ} \mathrm{C}$, light absorption of the sample was then measured by spectrophotometer. The activity is expressed in 4-nitrophenol (NP) mass produced by $1 \mathrm{~g}$ of dry organic sludge per hour.

\section{Results}

To see the Table 5 it can be said that in the thermophilic system - as a result of the higher utilisation of the organic materials - the specific gas production is higher which is according with former published results. Methane content of the biogas increased with $9.4 \%$ (mesophilic avarage: $54.2 \pm 3.9 \%$, thermophilic avarage: $59.3 \pm 2.3 \%$ ).

Neither of the investigated systems showed significant $\mathrm{pH}$ variation, its value was in reasonable interval in both of cases. Average $\mathrm{pH}$ value in the thermophilic system was about the minimum level (7.2 \pm 0.5$)$ of the optimal range. It can be said that the $\mathrm{pH}$ itself is not an adequate parameter for following the processes. Volatile acid's content changed according to the $\mathrm{pH}$ and its value is higher by the thermophilic fermentation $\left(3709 \pm 793 \mathrm{mgCH}{ }_{3} \mathrm{COOH} / \mathrm{dm}^{3}\right)$, at the same time bacterial utilization of volatile acid is also higher which can be confirmed by the larger gas output and methane content. In the relation of the above mentioned aspect the alkalinity value - as the buffer capacity of the system - was higher in the mesophilic system (average: $5982 \pm 951 \mathrm{mgCaCO}_{3} / \mathrm{dm}^{3}$ ). 
Table 5. Variation of control parameters and enzyme activities data in the full scale plant in mesophilic and thermophilic process over 50 days investigation period

\begin{tabular}{c|c|c|c|c}
\hline Parameters & \multicolumn{2}{|c|}{ Mesophilic system } & \multicolumn{2}{c}{ Thermophilic system } \\
Average & RSD (\%) & Average & RSD (\%) \\
\hline $\begin{array}{c}\text { Specific gas quantity } \\
\left(\mathrm{Nm}^{3} / 1000 \mathrm{~kg} \text { organic }\right. \\
\text { material) }\end{array}$ & 965 & 10.8 & 990 & 10.9 \\
$\begin{array}{c}\text { Methane content of the } \\
\text { biogas (\%) }\end{array}$ & 54.2 & 7.1 & 59.3 & 4.0 \\
pH & 7.8 & 3.7 & 7.2 & 6.3 \\
$\begin{array}{c}\text { Alkalinity } \\
\left.\text { (mgCaCO } / \mathrm{dm}^{3}\right)\end{array}$ & 5982 & 15 & 4658 & 25 \\
$\begin{array}{c}\text { Volatile acid } \\
\left(\mathrm{mgCH}_{3} \mathrm{COOH} / \mathrm{dm}^{3}\right)\end{array}$ & 2077 & 17 & 3709 & 21 \\
$\begin{array}{c}\text { Dehydrogenase (mg } \\
\text { TP/g org.m.*h) }\end{array}$ & 19.5 & 17.8 & 29.4 & 23.4 \\
$\begin{array}{c}\text { Protease (mg tyrosine/g } \\
\text { org.m.*h) }\end{array}$ & 119.7 & 25.4 & 154.6 & 19.8 \\
$\begin{array}{c}\text { Lipase (mg NP/g } \\
\text { org.m.*h) }\end{array}$ & 224.5 & 40.5 & 294.2 & 30.2 \\
\hline
\end{tabular}

$\mathrm{Nm}^{3}=$ normal $\mathrm{m}^{3}$ (in normal state: $273,15 \mathrm{~K}, 0,1 \mathrm{MPa}$ ), $\mathrm{TP}$ = triphenyl-phormazane, $\mathrm{NP}=$ 4-nitrophenol, org.m. $=$ organic material

All of the three enzyme activity's values were higher in the thermophilic fermentation than in the mesophilic one - due to the more intensive bacteria's activity which were indicated also by the larger gas output. Dehydrogenase activities as indicator of total biomass activities in the two different anaerobic systems is shown in the Fig. 1; the substrate specific protease activities can be seen in the Fig. 2 and the lipase activities is in the Fig. 3. The average values of the 50 days investigations are described in the Table 5. Based on the figures it can be said that the enzyme activity of the thermophilic system is higher than the mesophilic one in each case.

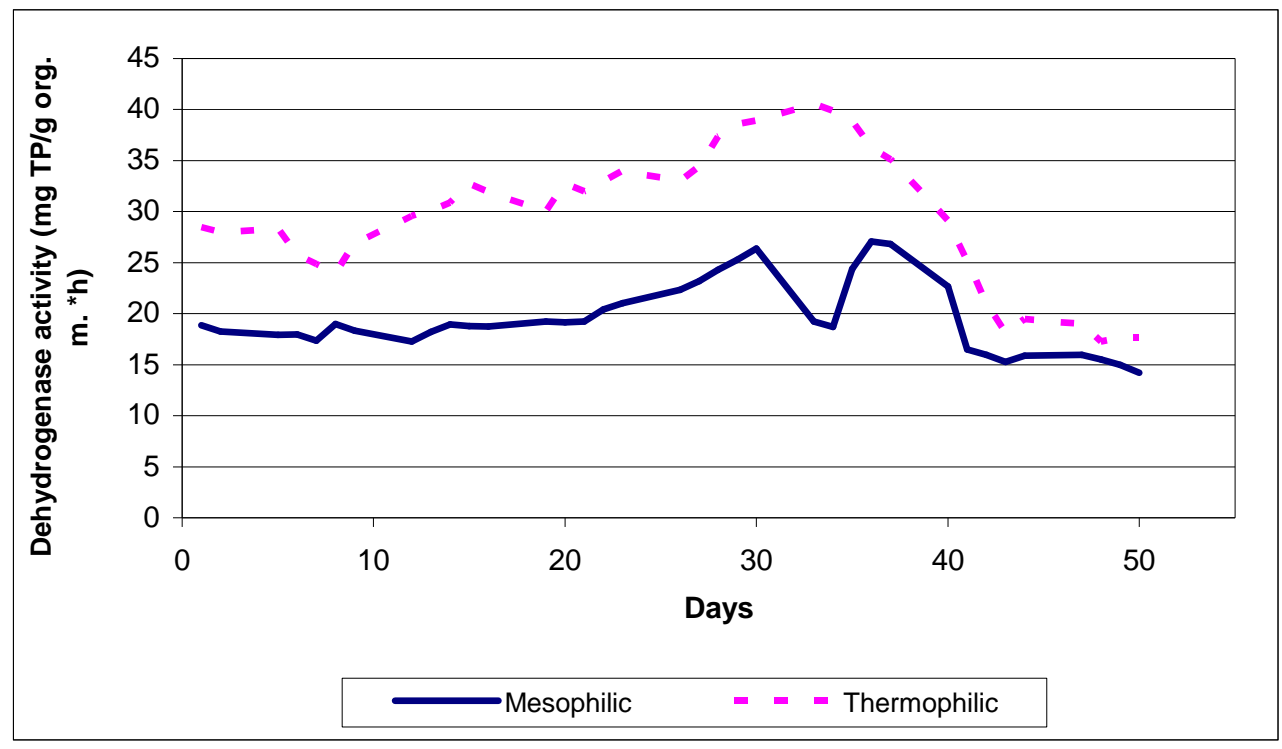

Figure 1. Variation of dehydrogenase activities in thermophilic and mesophilic systems $(T P=$ triphenyl-phormazane, org. $m .=$ organic material $)$ 


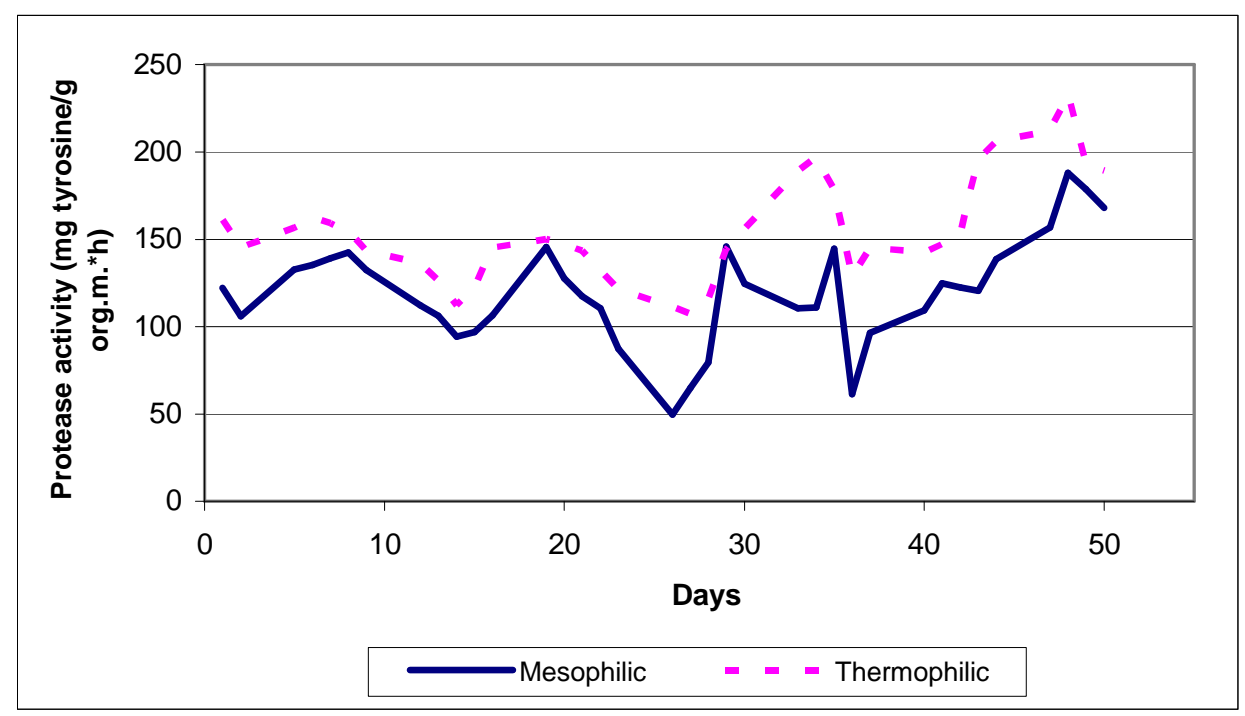

Figure 2. Variation of protease activities in thermophilic and mesophilic systems $($ org.m. $=$ organic material $)$

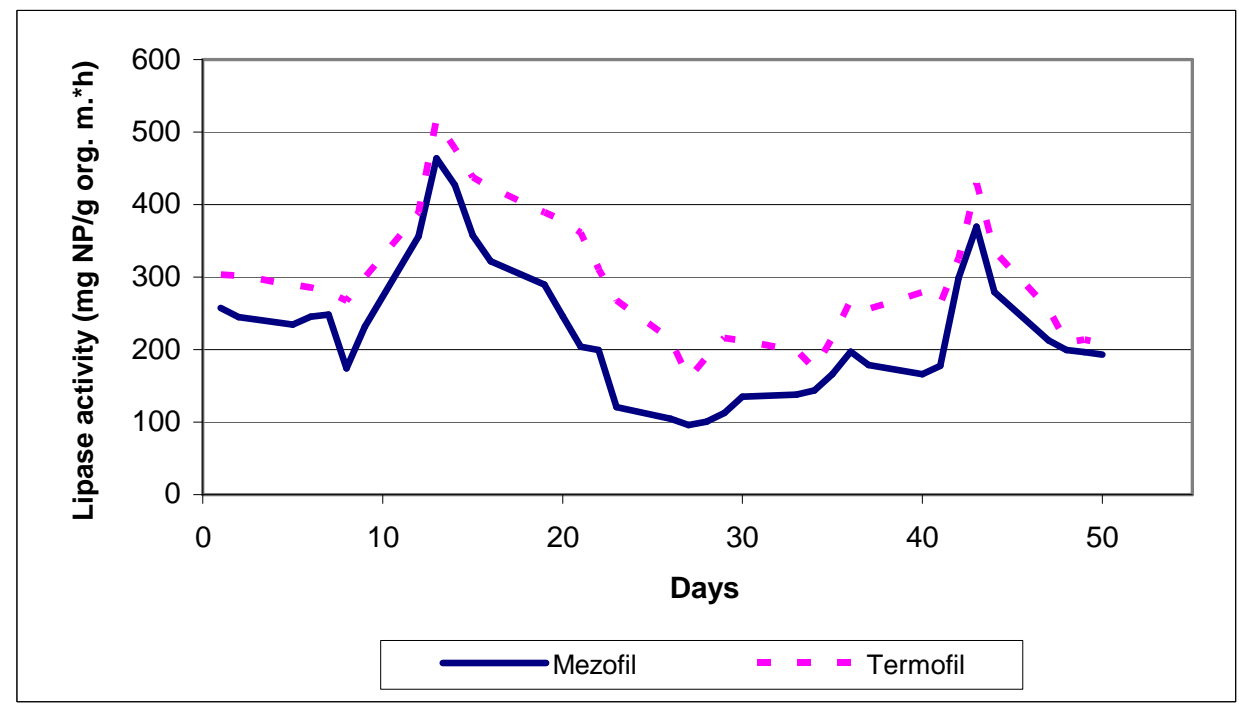

Figure 3. Variation of lipase activities in thermophilic and mesophilic systems $(N P=4$-nitrophenol, org.m. $=$ organic material $)$

\section{Summary}

Based on the 50 days investigations made in full scale plant anaerobic fermenters at mesophilic and thermophilic temperature, it can be said that the specific gas output of the thermophilic system is higher. Methane gas content - as indicator of the heater capacity - in the biogas increased from $54.2 \pm 3.9 \%$ to a value of $59.3 \pm 2.3$, this means $9.4 \%$ average growing. The average quantity of daily methane production increased from $523 \mathrm{Nm}^{3} / 1000 \mathrm{~kg}$ dry organic material to $587 \mathrm{Nm}^{3} / 1000 \mathrm{~kg}$ dry organic material which means $12.3 \%$ rising $\left(64.5 \mathrm{Nm}^{3}\right.$ methane). This important fact compensates that larger heat demand and smooth temperature's regulation are needed in the thermophilic fermenters. In this system the $1-2^{\circ} \mathrm{C}$ sudden temperature changes can cause operating 
trouble. Among the usually applied control parameters, $\mathrm{pH}$ has not shown significant variation in the two investigated systems, its value has stayed in the optimal interval thatswhy $\mathrm{pH}$, itself can not be adequate control parameter. The average values of the alkalinity in the mesophilic system was higher comparing to that at thermophilic temperature was observed, despite of it the system's buffer capacity was provided suitable by that. The system's buffer capacity is determined by the alkalinity which has crucial role in the safe plant operation. Increased volatile acid concentration and utilization were measured in the thermophilic system than those at mesophilic temperature and it is also confirmed by the larger specific gas production data. Thermophilic system proccesses higher enzyme activities than the mesophilic one. All of the three investigated biochemical parameters (dehydrogenase determining the total biomass activities, and the substrate specific protease and lipase) values were higher at thermophilic temperature. The biochemical activity parameters are proposed to apply for control the anaerobic digestion balance, as the first speed determining steps of the fermentation can be described by them. The advantage is that simplified enzyme activity tests require relatively short time and low investment costs also in low level equipped laboratories.

Acknowledgement. We express our thanks to the staff of the Wastewater Treatment Plant of South Pest, for operation of the plant- and pilot plant scale reactors and the Research and Development Group for their assistant. This research was supported by the TÁMOP 4.2.1/B-09/01/KMR/2010-0005 project.

\section{REFERENCES}

[1] Ahring, B.K. (1994): Status on science and application of thermophilic anaerobic digestion. - Water Science and Technology 30(12): 241-249.

[2] Aitken, M.D., Mullenix, R.W. (1992): Another look at thermophilic anaerobic digestion of wastewater sludge. - Water Environment Research 64(7): 915-919.

[3] Analysis of soil biological activity by method of dehydrogenase enzyme activity (1986). Soil analysis of agricultural land treated with sewage and sewage sludge. MSZ-08$1721 / 3-86$.

[4] Chung, Y.C., Neethling, J.B. (1988): ATP as a measure of anaerobic sludge digester activity. - Journal Water Pollution Control Federation 60: 107-112.

[5] Fair, G. M., Moore, E. W. (1934): Time and rate of sludge digestion and their variation with temperature. - Sewage Works Journal 6: 3-13.

[6] Garber, W.F. (1982): Operating experience with anaerobic digestion. - Journal WPCF 54(8): 1170-1175.

[7] García, C., Hernandez, T., Albaladejo, J., Castilla, V., Roldan, A. (1998): Revegetation in senierid zone: influence of terracinn gand organic refuse on microbial activity. - Soil Science Society of America Journal 62: 670-676.

[8] Goel, R., Mino, T., Satoh, H., Matsuo, T (1998): Enzyme activities under anaerobic and aerobic conditions in activated sludge sequencing batch reactor. - Water Reasearch 32(7): 2081-2088.

[9] Goulecke, C. (1958): Temperature effects on anaerobic digestion of raw sewage sludge. Sewage Industrial Wastes 30-35: 1225.

[10] Griebe, T., Schaule, G., Wuertz, S. (1997): Determination of microbial respiratory and redox activity in activated sludge. - Journal of Industrial Microbiology and Biotechnology 19(2): 118-122.

[11] Hills, D., J., Schroeder, E., D. (1969): Temperature effects on the rate of methane fermentation. - Water Sewage Works 6: 46-51. 
[12] Iranpour, R., Oh, S., Cox, H.J,. Shao, Y.J., Moghaddam, O., Kearney, R.J., Deshusses, M.K., Stenstrom, M.K., Ahring, B.K. (2002): Changing mesophilic wastewater sludge digestion into thermophilic operation at Terminal Island Plant. - Water Environment Research 74(5): 494-507.

[13] Kardos, L., Palkó, Gy., Oláh, J., Barkács, K., Záray, Gy. (2009): Operation control of anaerobic digesters on the basis of enzyme activity tests. - Water Science and Technology 64(4): 957-964.

[14] Lawrance, A. W. McCarty, P. L. (1969): Kinetics of methane fermentation in anaerobic treatment. - Journal Water Pollution Control Federation 41: 1-16.

[15] Li, Y., Chróst J. R. (2006): Microbial enzymatic activities in anaerobic activated sludge model. - Enzyme and Microbial Technology 39(4): 568-572.

[16] Malina, J.F., Pohland, F.G. (1992): Design of anaerobic processes for the treatment of industrial and municiapal wastes. - Water Quality Management Library 7: 2-18, 29-31, 167-184, 194-210.

[17] Moen, G., Stensel H.D., Lepistö, R., Ferguson, J.F. (2003): Effect of solids retention time on the performance of thermophilic and mesophilic digestion of combined municipal wastewater sludges. - Water Environment Research 75(6): 539-548.

[18] Mosey, F. E., Fernandes, X. A. (1988): Monitoring hydrogen in biogas during the anaerobic digestion of sugars. - In: Fifth International Symposium on Anaerobic Digestion, Bologna, Italy, 219-221.

[19] Nielsen, B. (1999): Thermophilic anaerobic digestion and pasteurisation. Practical experience from Danish Wastewater treatment plants. - Water Science and Technology 42: 65-72.

[20] Nielsen, B., Petersen, G. (2001): Thermophilic anaerobic digestion. Experience and effect on the hygienic quality of the sludge. - In: Nordic Conference on treatment of municipal wastewater. Copenhagen, January 17-19.

[21] Organic and volatile acids. Standard methods for the examination of water and wastewater (1995). 19th Edition. Publication Office American Public Health Association, 1015 Fifteenth Street, NW Washington, DC 2005.

[22] Rimkus, R.R., Ryan, J.M., Cook, E.J. (1982): Full-scale thermophilic digestion at the West-Southwest Sewage Treatment works, Chicago, Illinois. - Journal WPCF 54(11): 1447-1457.

[23] Raghuvanshi, S., P., Raghav, A. K., Chandra, A. (2008): Renewable energy resources for climate change mitigation. - Applied Ecology and Environmental Research 6(4): 15-27.

[24] Schroeder, E. D. (1977): Water and wastewater treatment: 313-337.

[25] Skujins, J. (1976): Enzymes in soil. - In: Mc Laren A.D., Peterson, G.H. (eds.). Soil Biochemistry, Marcel Dekker, Inc. New York, USA: 371-414.

[26] Thiel, P. G., Hattingh, W. H. J. (1967): Determination of hydrolytic enzyme activities in anaerobic digesting sludge. - Water Research 1: 191-196.

[27] Thiel, P. G., Toerien, D. F., Hattingh, W. H. J., Kotzé, J. P., Siebert, M. L. (1968): Interrelations between biological and chemical characteristics in anaerobic digestion. Water Research 2: 393-408.

[28] Titration Method. Standard methods for the examination of water and wastewater (1995). 19th Edition. Publication Office American Public Health Association, 1015 Fifteenth Street, NW Washington, DC 2005.

[29] Zábránská, J., Dohányos, M., Jenicek, P., Kutil, J. (2000): Thermophilic process and enhancement of excess activated sludge degradability-two ways of intensification of sludge treatment in the Prague central wastewater treatment plant. - Water Science and Technology 41: 265-272.

[30] Zábránská, J., Dohányos, M., Jenicek, P., Zaplatilkova, P., Kutil, J. (2002): The contribution of thermophilic anaerobic digestion to the stable operation of wastewater sludge treatment. - Water Science and Technology 46(4-5): 447-453. 
[31] Zábranská, J., Stepova, J., Wachti, R., Jenicek, P., Dohányos, M. (2000): The activity of anaerobic biomass in thermophilic and mesophilic digester at different loading rates. Water Science and Technology 42(9): 49-56.

[32] Vorderwülbecke, T., Kieslich, K., Erdmann, H. (1992): Comparison of lipases by different assays. - Enzyme Microbiological Technology 14: 631 - 639. 